\title{
Fasilitas, Aksesibilitas Dan Daya Tarik Wisata Terhadap Kepuasan Wisatawan
}

\author{
Sri Handayani ${ }^{1)}$, Khairiyansyah ${ }^{1)}$, Nanang Wahyudin ${ }^{1)^{*}}$ \\ Program Studi Manajemen Universitas Bangka Belitung \\ Kampus Terpadu Balunijuk, Kecamatan Merawang, Kabupaten Bangka \\ Provinsi Bangka Belitung 33172, Indonesia \\ *Email : nanang.w19@gmail.com
}

\begin{abstract}
Artikel Info ABSTRAK
Dikirim: Bangka Belitung merupakan provinsi kepulauan yang memiliki berbagai destinasi wisata, salah satunya adalah

27 Juni 2019 Bangka Botanical Garden $(B B G)$ yang merupakan kawasan wisata agro yang tidak hanya mengedepankan sistem

Revisi: pembibitan, tetapi juga bidang lainnya seperti pendidikan, penelitian, olahraga dan wisata. Penelitian ini bertujuan

15 Agustus 2019 untuk mengetahui pengaruh fasilitas, aksesibilitas dan daya tarik wisata terhadap kepuasan wisatawan berkunjung

5 Agustus 2019 ke Bangka Botanical Garden $(B B G)$ Pangkalpinang. Penelitian ini menggunakan pendekatan kuantitatif dengan
Diterima:

27 September 2019 jumlah sampel sebanyak 260 responden, sedangkan teknik pengambilan sampel dengan teknik non-probability sampling menggunakan metode accidental sampling. Variabel bebas pada penelitian ini terdiri dari fasilitas, aksesibilitas dan daya tarik wisata, sedangkan variabel terikatnya yaitu kepuasan wisatawan. Pengolahan data menggunakan analisis regresi linear berganda dengan uji t, uji F dan $\mathrm{R}^{2}$. Hasil penelitian menunjukkan bahwa pengujian terhadap hipotesis, baik secara parsial maupun simultan pada variabel fasilitas, aksesibilitas dan daya tarik wisata berpengaruh positif dan signifikan terhadap kepuasan wisatawan berkunjung ke Bangka Botanical Garden ( $B B G$ ) Pangkalpinang. Hal ini mengindikasikan bahwa semakin baik fasilitas, aksesibilitas dan daya tarik wisata yang tersedia di kawasan wisata Bangka Botanical Garden (BBG) Pangkalpinang maka akan meningkatkan kepuasan wisatawan berkunjung. Sedangkan untuk koefisien determinasi $\left(\mathrm{R}^{2}\right)$ sebesar $62,7 \%$ yang berarti variabel kepuasan wisatawan dapat dijelaskan oleh variabel fasilitas, aksesibilitas dan daya tarik wisata.
\end{abstract}

Kata Kunci: Fasilitas, Aksesibilitas, Daya Tarik Wisata dan Kepuasan Wisatawan

\section{Facilities, Accessibility and Travel Attraction on Tourist Satisfaction}

\begin{abstract}
Bangka Belitung is an archipelago province that has various tourist destinations, one of which is Bangka Botanical Garden (BBG) which is an agro tourism area that not only promotes nursery systems, but also other fields such as education, research, sports and tourism. This study aims to determine the effect of facility, accessibility and tourist attractiveness on tourist satisfaction visiting the Bangka Botanical Garden (BBG) Pangkalpinang. This Study uses a quantitative approach with a total sample of 260 respondents, while sampling techniques is non-probability sampling techniques using accidental sampling method. The independent variable in this study consists of facitily, accessibility, and tourist attractiveness, while the dependent variable is tourist satisfaction. Data processing uses multiple linear regression analysis with $T$ test, $F$ and $R^{2}$ test. The results showed that testing the hypotheses, both partially and simultaneously on facility variables, accessibilities and tourist attractiveness had a positive and significant effect on tourist satisfaction visiting Bangka Botanical Garden (BBG) Pangkalpinang. This indicated that the better the facilities, accessibilities and tourist attractiveness available in the Bangka Botanical Garden (BBG) tourism area of Pangkalpinang, the more tourist satisfaction increase. The coefficient of determination $\left(R^{2}\right)$ was $62.7 \%$, which means that the variables of tourist satisfaction can be explained by variable facilities, accessibility and tourist attractiveness.
\end{abstract}

Keyword : Facilities, Accessibility, Tourist Attractiveness and Tourists Satisfaction

Cara Sitasi :

Handayani, S., Khairiyansyah., \& Wahyudin, N. (2019). Fasilitas, Aksesibilitas Dan Daya Tarik Wisata Terhadap Kepuasan Wisatawan. Jurnal Ilmiah Manajemen dan Bisnis, 20(2), 123-133. https://doi.org/10.30596/jimb.v20i2.3228. 


\section{PENDAHULUAN}

Sumber daya alam yang terdapat di Indonesia sangatlah kaya dan melimpah, didukung oleh lautan dan dikelilingi oleh ribuan pulau serta berbagai kekayaan sumber daya alam menjadi potensi tersendiri bagi Indonesia untuk mengembangkan pariwisata khususnya di bidang alam (Mudrikah et al., 2014) Pariwisata merupakan sektor yang menyumbangkan penghasil devisa terbesar suatu negara serta dapat menciptakan lapangan pekerjaan, maka dari itu diperlukan upaya penggalian dan pengembangan potensi wisata lebih dalam (Prantawan P \& Sunarta, 2015)

Bangka Belitung lebih dikenal sebagai wilayah dengan objek wisata yang menyuguhkan keindahan pantai dan wisata bahari, padahal sebenarnya banyak pilihan wisata yang dapat ditemukan di Bangka Belitung salah satunya wisata agro seperti Bangka Botanical Garden $(B B G)$. Kawasan ini merupakan tempat pembibitan untuk berbagai jenis tanaman hijau seperti aglonema, patah tulang, kantong semar dan nilam, berbagai jenis buah-buahan seperti stoberi, jambu citra, dan jeruk serta berbagai jenis sayur-sayuran. Selain itu dari sektor peternakan, Bangka Botanical Garden (BBG) memiliki ternak unggulan yaitu sapi, terdapat berbagai jenis sapi yang dapat ditemukan disini seperti sapi potong, sapi perah dan sapi bali. Kemudian untuk sektor perikanan, terdapat ikan koi, ikan nila dan berbagai macam ikan hias yang terdiri dari ikan impor dan lokal yang semuanya bisa menghasilkan sekitar 70.000 ekor perharinya (Replianto, 2018).

Berdasarkan data yang diperoleh dari observasi peneliti di kawasan Bangka Botanical Garden (BBG) Pangkalpinang, bahwa jumlah pengunjung Bangka Botanical Garden (BBG) Pangkalpinang cenderung tidak stabil dimana selama seminggu mengalami kenaikan dan penurunan.
Tabel 1 Jumlah Wisatawan Bangka Botanical Garden ( $B B G$ ) Pangkalpinang pada Bulan Maret 2018

\begin{tabular}{lc}
\hline Hari & Jumlah Wisatawan \\
\hline Senin & 202 \\
Selasa & 222 \\
Rabu & 181 \\
Kamis & 262 \\
Jumat & 213 \\
Sabtu & 1721 \\
Minggu & 2301 \\
\hline Total & $\mathbf{5 1 0 2}$ \\
\hline Rata-rata & $\mathbf{7 2 8 . 8}$ \\
\hline
\end{tabular}

Sumber: Berdasarkan observasi peneliti, 2018

Pra survey terhadap 20 responden yang dilakukan peneliti menghasilkan bahwa terdapat beberapa faktor yang dapat memicu kepuasan wisatawan yang berkunjung ke Bangka Botanical Garden (BBG). Faktor-faktor seperti fasilitas, aksesibilitas serta daya tarik wisata menjadi beberapa tolak ukur dari kepuasan wisatawan dalam berkunjung ke objek wisata tersebut. Dilihat dari fasilitas, aksesibilitas dan daya tarik wisata yang ada di kawasan Bangka Botanical Garden (BBG) sudah cukup baik. Namun jika dilihat, fasilitas yang disediakan belum cukup untuk memenuhi kebutuhan wisatawan, masih terdapat banyak kekurangan seperti jumlah wc umum yang terbatas, petunjuk jalan yang tidak lengkap, lahan parkir yang tidak tertata, serta pondok-pondok yang disediakan kurang terawat. Kemudian untuk aksesibilitasnya, masih terdapat beberapa jalan yang kondisinya berlubang sehingga menggangu wisatawan ketika melewatinya. Sedangkan untuk daya tarik wisatanya masih terdapat banyak lahan kosong yang tidak dimanfaatkan serta belum adanya ikon khusus yang menjadi ciri khas Bangka Botanical Garden (BBG).

Persaingan yang terjadi di berbagai industri menuntut setiap perusahaan agar selalu berusaha bertahan, salah satu caranya dapat dilakukan melalui pemberian pelayanan secara maksimal kepada setiap konsumen. Dalam hal ini diartikan sebagai jasa atau service yang diberikan dari 
pemilik jasa berupa kemudahan, kecepatan, hubungan, kemampuan dan keramahtamaan yang ditujukan melalui sikap dan sifat dalam memberikan pelayanan untuk kepuasan konsumen (Minrohayati., Harsasi, M., \& Pujiastuti, 2017) Agar terciptanya kepuasan wisatawan, pihak pengelola seharusnya menyediakan berbagai kebutuhan agar dapat memudahkan wisatawan dalam melakukan kegiatan wisata. Terdapat beberapa unsur pariwisata yang menjadi pengaruh dari pengembangan suatu produk wisata seperti daya tarik wisata, aksesibilitas dan fasilitas (Suryadana dan Octavia, 2015).

Berdasarkan penelitian terdahulu yang telah diuraikan diatas dan berdasarkan hasil pra Survey maka Penelitian ini bertujuan untuk mengidentifikasi dan menganalisis faktor apa saja yang berpengaruh terhadap kepuasan wisatawan berkunjung ke Bangka Botanical Garden (BBG) Pangkalpinang yang nantinya agar dapat dijadikan pertimbangan dalam pengembangan .

\section{Pengaruh Fasilitas terhadap Kepuasan Wisatawan}

Untuk memenuhi kebutuhan perjalanan, perlu disediakan berbagai macam fasilitas, mulai dari pemenuhan kebutuhan sejak berangkat dari tempat tinggal wisatawan, selama berada di destinasi pariwisata sampai kembali ke tempat semula. Fasilitas-fasilitas untuk memenuhi kebutuhan perjalanan wisatawan tersebut muncul dalam satu kesatuan yang saling berkaitan dan melengkapi satu sama lain, sehingga dalam suatu perjalanan wisata, seluruh komponen yang digunakan tidak dapat dipisahkan, tergantung pada karakteristik dan bentuk perjalanan wisata yang dilakukan oleh wisatawan (Suryadana dan Octavia, 2015:49).

Ketersediaan fasilitas di suatu objek wisata sangat penting untuk memenuhi kebutuhan wisatawan selama berada di objek wisata tersebut, fasilitas sangat berpengaruh dengan bagaimana wisatawan memandang objek wisata tersebut. Ketika semua fasilitas sudah disediakan dengan baik, hal ini tentunya membuat wisatawan nyaman dan puas telah berkunjung ke objek wisata tersebut. Penelitian yang dilakukan oleh Wulandari dan Wahyuati (2017) dengan judul Pengaruh Fasilitas, Pelayanan dan Harga Terhadap Kepuasan Wisatawan. Hasil penelitian tersebut diketahui bahwa variabel fasilitas, pelayanan,dan harga berpengaruh positif terhadap kepuasan pelanggan di Kenjeran Park Surabaya. Hipotesis pertama dalam penelitian ini adalah:

$\mathrm{H}_{1}$ : Fasilitas secara parsial diduga berpengaruh positif dan signifikan terhadap kepuasan wisatawan berkunjung ke Bangka Botanical Garden ( $B B G)$ Pangkalpinang.

\section{Pengaruh Aksesibilitas Terhadap Kepuasan Wisatawan}

Aksesibilitas merupakan salah satu unsur utama dalam produk karena mendorong pasar potensial menjadi pasar nyata, aksesibilitas mencakup transportasi masuk ke negara, inter dan intra region (daerah) serta di dalam kawasan, dan kemudahan memperoleh informasi tentang destinasi (Suryadana dan Octavia, 2015:56). Aksesibilitas merupakan salah satu hal yang penting dalam menunjang kelancaran berwisata. Dalam kasus ini yaitu aksesibilitas di dalam kawasan Bangka Botanical Garden (BBG), akses jalan yang baik di kawasan wisata merupakan salah satu faktor penting terjadinya kepuasan wisatawan. Wisatawan pun akan mendapat kualitas wisata yang lebih nyaman pada saat aksesibilitas dalam kondisi baik dan membuat kegiatan wisata yang mereka lakukan menjadi lancar.

Penelitian yang dilakukan (Wulandari, 2017) yang berjudul Pengaruh Physical Evidence, Aksesibilitas, dan Pelayanan Terhadap Kepuasan Konsumen Pada Hotel dan Resto Mitra Inn Kediri. Hasil dari penelitian ini secara parsial physical evidence tidak berpengaruh terhadap kepuasan konsumen sedangkan aksesibilitas dan pelayanan berpengaruh terhadap kepuasan konsumen. Secara simultan physical evidence, aksesibilitas, dan pelayanan 
berpengaruh terhadap kepuasan konsumen pada Hotel dan Resto Mitra Inn Kediri. Hipotesis kedua dalam penelitian ini adalah:

$\mathrm{H}_{2}$ : Aksesibilitas secara parsial diduga berpengaruh positif dan signifikan terhadap kepuasan wisatawan berkunjung ke Bangka Botanical Garden (BBG) Pangkalpinang.

\section{Pengaruh Daya Tarik Wisata Terhadap Kepuasan Pelanggan}

Daya tarik wisata adalah unsur terkuat dalam sistem pariwisata. Jika dibandingkan dengan unsur-unsur lain pembentuk produk pariwisata, daya tarik wisata merupakan pull faktor bagi wisatawan dalam mempengaruhi pengambilan keputusan mengunjungi suatu destinasi pariwisata. No Attraction, No Destination (Suryadana dan Octavia, 2015:56). Daya tarik wisata yang ada di suatu objek wisata menjadi salah satu alasan wisatawan untuk mengunjungi tempat tersebut. Ketika ada hal yang menarik perhatian wisatawan tentunya membuat ketertarikan sehingga wisatawan ingin mengunjungi tempat tersebut.

Penelitian yang dilakukan oleh (Rosyidah et al., 2017) dengan judul Pengaruh Daya Tarik Wisata dan Fasilitas Layanan Terhadap Kepuasan Wisatawan di Pantai Balekambang Kabupaten Malang. Hasil penelitian menunjukkan bahwa Daya Tarik Wisata dan Fasilitas Layanan secara bersama sama bepengaruh signifikan tehadap Kepuasan Wisatawan, Daya Tarik Wisata berpegaruh signifikan terhadap kepuasan Wisatawan, dan Fasilitas Layanan berpengaruh signifikan terhadap Kepuasan Wisatawan. Hipotesis ketiga dalam penelitian ini adalah:

$H_{3}$ : Daya tarik wisata secara parsial diduga berpengaruh positif dan signifikan terhadap kepuasan wisatawan berkunjung ke Bangka Botanical Garden (BBG) Pangkalpinang.

Pengaruh Fasilitas, Aksesibilitas, Daya Tarik Wisata terhadap Kepuasan Wisatawan

Kepuasan wisatawan dapat dipengaruhi oleh beberapa faktor seperti fasilitas, aksesibilitas dan daya tarik wisata serta faktor lain yang dapan mempengaruhi kepuasan wisatawan atas berbagai pilihan jasa yang dirasakan. Penelitian yang dilakukan oleh Prasojo (2017) yang berjudul Pengaruh Fasilitas, Kualitas Pelayanan, dan Aksesibilitas Terhadap Kepuasan Pasien di Rumah Sakit Gigi dan Mulut Institut Ilmu Kesehatan Bhakti Wiyata Kediri. Hasil penelitian menunjukkan bahwa terdapat pengaruh signifikan fasilitas, kualitas pelayanan, dan aksesibilitas terhadap kepuasan pasien di RSGM IIK Bhakti Wiyata Kediri. Hipotesis keempat dalam penelitian ini adalah:

$\mathrm{H}_{4}$ : Fasilitas, Aksesibilitas dan Daya Tarik Wisata secara simultan diduga berpengaruh positif dan signifikan terhadap kepuasan wisatawan berkunjung ke Bangka Botanical Garden (BBG) Pangkalpinang.

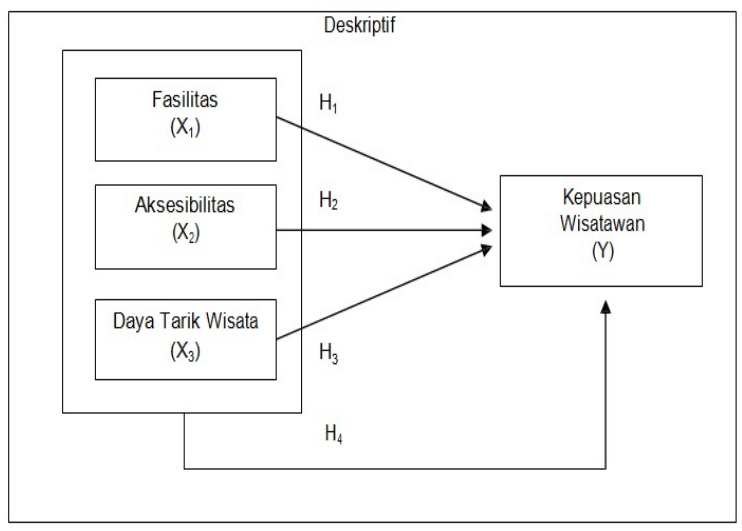

Gambar 1. Model Penelitian

\section{METODE}

Metode kuantitatif dengan statistik deskriptif serta statistik inferensial merupakan metode yang dilakukan dalam penelitian ini. Penelitian dilakukan di kawasan wisata Bangka Botanical Garden (BBG) Pangkalpinang. Variabel yang digunakan ada empat yaitu (1) Fasilitas, (2) Aksesibilitas, (3) Daya Tarik Wisata dan (4) Kepuasan Wisatawan.

Populasi dari penelitian ini diambil dari jumlah wisatawan yang berkunjung ke Bangka Botanical Garden (BBG) Pangkalpinang pada 19 Maret 2018 - 25 Maret 2018 yaitu sebanyak 729 
pengunjung, jumlah ini diperoleh dari rata-rata jumlah wisatawan yang berkunjung selama satu minggu.

Sedangkan untuk metodenya menggunakan metode nonprobability sampling yaitu accidental sampling yang merupakan teknik penentuan sampel berdasarkan kebetulan, siapa saja yang secara kebetulan/insidental bertemu dengan peneliti maka dapat digunakan sebagai sampel jika dipandang orang yang bersangkutan layak digunakan untuk menjadi sumber data (Sugiyono, 2015). Dalam penelitian ini, responden yang dipilih yaitu wisatawan yang sudah pernah berkunjung ke Bangka Botanical Garden ( $B B G$ ) Pangkalpinang, kemudian didapat hasil 260 responden/sampel.

\section{HASIL DAN PEMBAHASAN}

Hasil penyebaran kuesioner yang dilakukan terhadap 260 responden yang telah melakukan wisata ke Bangka Botanical Garden (BBG) Pangkalpinang. Kuesioner yang telah disebarkan kepada responden kemudian menghasilkan gambaran karakteristik responden dan hasil statistik deskriptif yaitu: Berdasarkan karakteristik responden dari sisi usia di dominasi yaitu pada rentang $18-29$ Tahun yang mengartikan lokasi wisata sangat diminati oleh remaja hingga dewasa yang tentunya sesuai dengan daya Tarik yang dimiliki seperti objek yang bagus untuk berfoto, dari sisi jenis kelamin di dominasi oleh perempuan sebesar 60\%, sedangkan dari sisi pekerjaan di dominasi oleh pelajar dan mahasiswa. Adapun informasi deskripsi lainnya berdasarkan intensitas kunjungan $43 \%$ dari responden menjawab lebih dari 3 kali dalam satu bulan mengartikan responden menunjukan tingkat kepuasan yang tinggi serta sangat tepat dalam penelitian ini dan mampu memberikan penilaian yang sebagaimana mestinya, dan kunjungan terakhir pada saat penelitian ini $63,8 \%$ responden berkunjung 1 bulan yang lalu.
Uji validitas digunakan untuk mengukur ke akuratan ataupun ketepatan sebuah item pertanyaan dalam mengukur sebuah variabel penelitian, sedangkan uji reliabilitas diperuntukan untuk mengetahui ke konsistenan sebuah item pertanyaan yang diajukan pada responden adapun hasilnya sebagai berikut :

Tabel 2. Uji Validitas

\begin{tabular}{|c|c|c|c|}
\hline & Indikator & r hitung & $r$ tabel \\
\hline \multirow[t]{4}{*}{ Fasilitas } & $\begin{array}{l}\text { Papan petunjuk } \\
\text { informasi }\end{array}$ & 0,804 & 0,121 \\
\hline & Tempat parkir & 0,726 & 0,121 \\
\hline & Pelayanan informasi & 0,839 & 0,121 \\
\hline & Pelayanan keamanan & 0,732 & 0,121 \\
\hline \multirow[t]{4}{*}{ Aksesibilitas } & $\begin{array}{l}\text { Petunjuk jalan } \\
\text { menuju lokasi }\end{array}$ & 0,736 & 0,121 \\
\hline & Rambu lalu lintas & 0,709 & 0,121 \\
\hline & Kondisi jalan & 0,731 & 0,121 \\
\hline & Kemudahan akses & 0,772 & 0,121 \\
\hline \multirow[t]{6}{*}{ Daya Tarik } & Perkebunan & 0,768 & 0,121 \\
\hline & Danau & 0,693 & 0,121 \\
\hline & Rumah adat & 0,828 & 0,121 \\
\hline & Pondok-pondok & 0,751 & 0,121 \\
\hline & Peternakan sapi & 0,672 & 0,121 \\
\hline & Spot foto & 0,640 & 0,121 \\
\hline \multirow[t]{6}{*}{ Kepuasan } & $\begin{array}{l}\text { Barang atau jasa yang } \\
\text { sesuai dengan } \\
\text { harapan }\end{array}$ & 0,742 & 0,121 \\
\hline & $\begin{array}{l}\text { Kepuasan terhadap } \\
\text { barang atau jasa }\end{array}$ & 0,800 & 0,121 \\
\hline & Kinerja aktual & 0,594 & 0,121 \\
\hline & $\begin{array}{l}\text { Tingkat keberhasilan } \\
\text { kinerja aktual barang } \\
\text { atau jasa }\end{array}$ & 0,841 & 0,121 \\
\hline & $\begin{array}{l}\text { Pengalaman } \\
\text { konsumen }\end{array}$ & 0,686 & 0,121 \\
\hline & $\begin{array}{l}\text { Harapan sebelum } \\
\text { pembelian sesuai } \\
\text { dengan persepsi }\end{array}$ & 0,788 & 0,121 \\
\hline
\end{tabular}

Berdasarkan hasil yang diperoleh, dimana semua pernyataan mendapatkan nilai $r$ hitung lebih besar dari $r$ tabel yaitu 0,121. Disimpulkan bahwa seluruh kuesioner dalam penelitian dinyatakan valid yang mengartikan dapat dilanjutkan pada proses analisis selanjutnya. 
Berdasarkan uji reliabilitas dimana hasil semua variabel menunjukkan nilai koefisien alpha diatas 0,70 , hal ini berarti bahwa kuesioner yang digunakan dalam penelitian ini merupakan kuesioner yang reliabel atau handal.

Dalam penelitian penggunaan sampel, maka perlu dilakukan uji normalitas data, untuk mengetahui data yang telah terkumpul sebarannya berdistribusi normal atau tidak, maka dari itu itu perlu dilakukan suatu pembuktian dengan uji statistik dalam penelitian ini menggunakan kolmogorov smirnov test dengan hasil pada tabel 4 .

Tabel 4. Hasil Uji Normalitas

\begin{tabular}{llr}
\hline & & $\begin{array}{c}\text { Unstandardized } \\
\text { Residual }\end{array}$ \\
\hline $\mathrm{N}$ & & 260 \\
Normal Parameters & Mean &, 0000000 \\
& Std. Deviation & 2,30842909 \\
Most Extreme & Absolute &, 044 \\
Differences & Positive &, 041 \\
& Negative &,- 044 \\
Test Statistic & &, 044 \\
Asymp. Sig. (2-tailed) & &, $200^{\mathrm{c}, \mathrm{d}}$ \\
\hline
\end{tabular}

Diketahui bahwa nilai asymp.sig (2.tailed) sebesar 0,200, hal ini berarti residual berdistribusi normal karena lebih dari 0,05 sehingga dapat dikatakan sebaran data dalam penelitian ini normal/wajar.

Analisis ini digunakan untuk mengetahui besarnya pengaruh yang diberikan variabel independen (fasilitas, aksesibilitas dan daya tarik wisata) terhadap variabel dependen (kepuasan wisatawan) adapun hasilnya dapat dilihat pada tabel 5.

Tabel 5. Hasil Analisis Regresi Berganda

\begin{tabular}{lllc}
\hline \multirow{2}{*}{ Model } & \multicolumn{2}{l}{$\begin{array}{l}\text { Unstandardized } \\
\text { Coefficients }\end{array}$} & $\begin{array}{l}\text { Standardized } \\
\text { Coefficients }\end{array}$ \\
\cline { 2 - 4 } & B & Std. Error & Beta \\
\hline (constant) & 1,948 &, 975 & \\
Fasilitas &, 480 &, 065 &, 351 \\
Aksesibilitas &, 260 &, 068 &, 181 \\
Daya Tarik &, 420 &, 041 &, 447 \\
\hline
\end{tabular}

\section{Wisata}

Hasil analisis persamaan regresi linier berganda dapat dinterprestasikan sebagai berikut:

$$
Y=1,948+0,480 x_{1}+0,260 x_{2}+0,420 x_{3}
$$

Nilai konstanta sebesar 1,948, hal ini berarti ketika variabel fasilitas, aksesibilitas dan daya tarik wisata bernilai 0 , maka nilai kepuasan wisatawan sebesar 1,948. Sehingga dapat disimpulkan bahwa tanpa ada variabel fasilitas, aksesibilitas dan daya tarik wisata maka kepuasan wisatawan akan sebesar 1,948 satuan. Nilai koefisien regresi fasilitas $\left(x_{1}\right)=0,480$ Variabel fasilitas sebesar 0,480 mempengaruhi kepuasan wisatawan atau berpengaruh positif terhadap kepuasan wisatawan. Jika nilai variabel fasilitas meningkat sebesar satu sedangkan variabel lain tetap, maka akan berpengaruh naiknya nilai variabel kepuasan wisatawan sebesar 0,480. Nilai koefisien regresi aksesibilitas $\left(x_{2}\right)=0,260$. Variabel aksesibilitas sebesar 0,260 mempengaruhi kepuasan wisatawan atau berpengaruh positif terhadap kepuasan wisatawan. Jika nilai variabel aksesibilitas meningkat sebesar satu sedangkan variabel lain tetap, maka akan mempengaruhi naiknya nilai variabel kepuasan wisatawan sebesar 0,260. Nilai koefisien regresi daya tarik wisata $\left(x_{3}\right)=0,420$. Variabel daya tarik wisata sebesar 0,420 mempengaruhi kepuasan wisatawan atau berpengaruh positif terhadap kepuasan wisatawan. Jika nilai variabel daya tarik wisata meningkat sebesar satu sedangkan variabel lain tetap, maka akan mempengaruhi naiknya nilai variabel kepuasan wisatawan sebesar 0,420 .

Uji t dilakukan untuk melihat seberapa jauh pengaruh variabel independen secara parsial terhadap variabel dependen dan sebagai pembuktian sebuah hipotesis diterima atau ditolak berdasarkan hasil uji $t$ hitung dibandingkan dengan $t$ tabel, dapat dilihat pada tabel berikut ini : 
Tabel 6. Hasil Uji t

\begin{tabular}{lcl}
\hline \multicolumn{1}{c}{ Model } & T & Sig \\
\hline (constant) & 1,997 &, 047 \\
Fasilitas & 7,431 &, 000 \\
Aksesibilitas & 3,821 &, 000 \\
Daya Tarik Wisata & 10,245 &, 000 \\
\hline
\end{tabular}

Hasil koefisien melalui pengujian hipotesis dan kemudian dibandingkan dengan $\mathrm{t}$ tabel yaitu $\mathrm{n}=$ jumlah sampel 260 dengan $\alpha=0,05$, maka didapat $t$ tabel sebesar 1,650 kemudian dari hasil tiap-tiap variabel dapat diketahui variabel manakah yang berpengaruh terhadap kepuasan wisatawan. $\mathrm{H}_{1}$ : Uji hipotesis fasilitas terhadap kepuasan wisatawan dari hasil perhitungan yang diperoleh t hitung untuk $X_{1}$ sebesar 7,431 lebih besar dari $t$ tabel 1,650 dengan signifikansi sebesar 0,000 lebih kecil dari taraf signifikansi 0,05 . Berdasarkan hal tersebut maka dapat ditarik kesimpulan bahwa $\mathrm{H}_{1}$ diterima dan Ho ditolak, hal ini menunjukkan variabel fasilitas berpengaruh positif dan signifikan terhadap kepuasan wisatawan. $\mathrm{H}_{2}$ : Uji hipotesis aksesibilitas terhadap kepuasan wisatawan dari hasil perhitungan yang diperoleh $\mathrm{t}$ hitung untuk $X_{2}$ sebesar 3,821 lebih besar dari t tabel 1,650 dengan signifikansi sebesar 0,000 lebih kecil dari taraf signifikansi 0,05. Berdasarkan hal tersebut maka dapat ditarik kesimpulan bahwa $\mathrm{H}_{2}$ diterima dan Ho ditolak, hal ini menunjukkan variabel aksesibilitas berpengaruh positif dan signifikan terhadap kepuasan wisatawan. $\mathrm{H}_{3}$ : Uji hipotesis daya tarik wisata terhadap kepuasan wisatawan dari hasil perhitungan yang diperoleh t hitung untuk $X_{3}$ sebesar 10,245 lebih besar dari $\mathrm{t}$ tabel 1,650 dengan signifikansi sebesar 0,000 lebih kecil dari taraf signifikansi 0,05. Berdasarkan hal tersebut maka dapat ditarik kesimpulan bahwa $\mathrm{H}_{3}$ diterima dan Ho ditolak, hal ini menunjukkan variabel daya tarik wisata berpengaruh positif dan signifikan terhadap kepuasan wisatawan.

Uji F dilakukan untuk melihat seberapa jauh pengaruh variabel independen secara simultan terhadap variabel dependen dan sebagai pembuktian sebuah hipotesis diterima atau ditolak berdasarkan hasil uji $f$ hitung dibandingkan dengan $\mathrm{f}$ tabel, dapat dilihat pada tabel 7.

Tabel 7. Hasil Uji F

\begin{tabular}{lccccc}
\hline Model & $\begin{array}{c}\text { Sum of } \\
\text { Squares }\end{array}$ & Df & $\begin{array}{l}\text { Mean } \\
\text { Square }\end{array}$ & F & Sig \\
\hline Regression & 2324,983 & 3 & 774,994 & 143, &, 000 \\
& & & & 749 & \\
Residual & 1380,171 & 256 & 5,391 & & \\
Total & 3705,154 & 259 & & & \\
\hline
\end{tabular}

Hasil perhitungan uji $\mathrm{F}$, dilihat bahwa nilai $\mathrm{F}$ hitung sebesar 143,749 dan $\mathrm{F}$ tabel dengan df $1=$ derajat pembilangan 3 dan df $2=$ derajat penyebut 256 dengan taraf 5\% maka didapat $\mathrm{F}$ tabel sebesar 2,63 berarti $\mathrm{F}$ hitung $>\mathrm{f}$ tabel. Hasil $\rho=0,000<0,05$ maka Ho ditolak dan Ha diterima. Kemudian pada hasil uji $\mathrm{F}$ dapat ditarik kesimpulan dimana variabel independen secara simultan mempengaruhi variabel dependen secara signifikan. Berdasarkan analisis dapat disimpulkan bahwa variabel fasilitas, aksesibilitas dan daya tarik wisata berpengaruh positif dan signifikan secara simultan terhadap kepuasan wisatawan.

Koefisien Determinasi (R2) pada intinya mengukur seberapa jauh kemampuan model dalam menerangkan variasi variabel dependen. Nilai koefisien determinasi adalah antara nol dan satu. Nilai R2 yang kecil berarti kemanpuan variabel-variabel independen dalam menjelaskan variasi variabel dependen amat terbatas. Nilai yang mendekati satu berarti variabel-variabel independen memberikan hampir semua informasi yang dibutuhkan untuk memprediksi variasi variabel dependen (Ghozali, 2013:97).

Tabel 8. Hasil Analisis Koefisien Determinasi Model Change Statistic 


\begin{tabular}{|c|c|c|c|c|}
\hline & $\mathbf{R}$ & R Square & $\begin{array}{l}\text { Adjusted R } \\
\text { Square }\end{array}$ & $\begin{array}{l}\text { Std. Error } \\
\text { of the } \\
\text { Estimate }\end{array}$ \\
\hline 1 &, 792 & ,627 &, 623 & 2,322 \\
\hline
\end{tabular}

Hasil koefisien determinasi yang diperoleh menunjukkan angka $R$ Square 0,627. Hal ini mengatakan variabel kepuasan wisatawan dapat dijelaskan oleh variabel fasilitas, aksesibilitas dan daya tarik wisata yaitu sebesar $62,7 \%$, sedangkan sisanya dijelaskan oleh variabel lain diluar penelitian ini

\section{Pembahasan}

Variabel fasilitas, aksesibilitas, daya tarik wisata dan kepuasan wisatawan masuk dalam kategori tinggi. Variabel fasilitas menunjukkan nilai rata-rata sebesar 3,41 (Tinggi), variabel aksesibilitas menunjukkan nilai rata-rata sebesar 3,51 (Tinggi), variabel daya tarik wisata menunjukkan nilai rata-rata sebesar 3,79 (Tinggi) dan kepuasan wisatawan menunjukkan nilai ratarata sebesar 3,62 (Tinggi).

Berdasarkan hasil penelitian uji parsial diperoleh $\mathrm{t}$ hitung untuk $X_{1}$ sebesar 7,431 lebih besar dari $t$ tabel 1,650 dengan signifikansi sebesar 0,000 lebih kecil dari taraf signifikansi 0,05. Jika dilihat dari nilai coefficients betta yaitu 0,480, maka variabel fasilitas berpengaruh terhadap kepuasan wisatawan sebesar $48 \% . \mathrm{H}_{1}$ diterima dimana Fasilitas secara parsial berpengaruh positif dan signifikan terhadap kepuasan wisatawan berkunjung ke Bangka Botanical Garden (BBG) Pangkalpinang.

Setiap tempat wisata sebisa mungkin harus dapat menyediakan fasilitas untuk memenuhi segala kebutuhan wisatawan. Hasil penelitian ini mendukung penelitian terdahulu yang dilakukan oleh: 1)(Wulandari, V., dan Wahyuati, 2017) dengan judul Pengaruh Fasilitas, Pelayanan dan Harga Terhadap Kepuasan Wisatawan. Hasil penelitian tersebut diketahui bahwa variabel fasilitas berpengaruh positif terhadap kepuasan pelanggan di Kenjeran Park Surabaya dan 2) (Marhanah \& Wahadi, 2016) dengan judul Pengaruh Fasilitas Wisata dan Kualitas Pelayanan terhadap Kepuasan Pengunjung di
Taman Margasatwa Ragunan Jakarta. Hasil dari penelitian ini menunjukan bahwa keadaaan fasilitas wisata, kualitas pelayanan dan kepuasan pengunjung di TMR dinilai baik oleh responden dimana fasilitas wisata dan kualitas pelayanan berpengaruh positif terhadap kepuasan pengunjung di TMR.

Berdasarkan hasil penelitian uji parsial diperoleh t hitung untuk $X_{2}$ sebesar 3,821 lebih besar dari $\mathrm{t}$ tabel 1,650 dengan signifikansi sebesar 0,000 lebih kecil dari taraf signifikansi 0,05. Jika dilihat dari coefficients betta 0,260, yang berarti aksesibilitas berpengaruh terhadap kepuasan wisatawan sebesar $26 \% . \mathrm{H}_{2}$ diterima dimana Aksesibilitas secara parsial memiliki pengaruh positif dan signifikan terhadap kepuasan wisatawan berkunjung ke Bangka Botanical Garden (BBG) Pangkalpinang.

Aksesibilitas adalah salah satu unsur utama dalam sebuah produk karena mendorong terjadinya pasar potensial menjadi pasar nyata (Suryadana dan Octavia, 2015:56). Hasil penelitian ini mendukung penelitian terdahulu yang dilakukan oleh : 1) (Wulandari, 2017) berjudul Pengaruh Physical Evidence, Aksesibilitas, dan Pelayanan Terhadap Kepuasan Konsumen Pada Hotel dan Resto Mitra Inn Kediri. Hasil dari penelitian ini secara parsial aksesibilitas berpengaruh terhadap kepuasan konsumen dan 2) (Wanda \& Pangestuti, 2018) yang berjudul Pengaruh Pengembangan Komponen Destinasi Wisata terhadap Kepuasan Pengunjung (Survei pada Pengunjung Situs Trowulan). Hasil penelitian menunjukkan bahwa terdapat pengaruh signifikan antara komponen pengembangan destinasi wisata (atraksi wisata, aksesibilitas, amenitas, dan fasilitas tambahan) terhadap kepuasan pengunjung di Situs Trowulan.

Berdasarkan hasil penelitian uji parsial diperoleh thitung untuk $X_{3}$ sebesar 10,245 lebih besar dari t tabel 1,650 dengan signifikansi sebesar 0,000 lebih kecil dari taraf signifikansi 0,05. Jika dilihat dari nilai coefficients betta yaitu 0,420, maka variabel daya tarik wisata 
berpengaruh terhadap kepuasan wisatawan sebesar $42 \% . \mathrm{H}_{3}$ diterima dimana Daya Tarik Wisata secara parsial memiliki pengaruh positif dan signifikan terhadap kepuasan wisatawan berkunjung ke Bangka Botanical Garden (BBG) Pangkalpinang.

Pengambilan keputusan yang dilakukan oleh wisatawan untuk mengunjungi suatu destinasi wisata dapat dipengaruhi oleh daya tarik wisata (Suryadana dan Octavia, 2015:56). Penelitian ini mendukung penelitian yang dilakukan oleh (Rosyidah et al., 2017) dengan judul Pengaruh Daya Tarik Wisata dan Fasilitas Layanan Terhadap Kepuasan Wisatawan di Pantai Balekambang Kabupaten Malang. Hasil penelitian menunjukkan bahwa Daya Tarik Wisata bepengaruh signifikan tehadap Kepuasan Wisatawan.

Nilai $\mathrm{F}$ hitung sebesar 143,749 dan F tabel dengan $\mathrm{df}_{1}=$ derajat pembilang 3 dan $\mathrm{df}_{2}=$ derajat penyebut 256 dengan taraf $5 \%$ maka didapat $F$ tabel sebesar 2,65 berarti $F$ hitung $>\mathrm{f}$ tabel. Hasil $\rho=0,000<0,05$. Pada hasil uji $\mathrm{F}$ variabel fasilitas, aksesibilitas dan daya tarik wisata memiliki pengaruh positif dan signifikan secara simultan terhadap kepuasan wisatawan. Sedangkan untuk koefisien determinasi $\left(\mathrm{R}^{2}\right)$ menunjukkan angka $R$ Square 0,627 yang berarti variasi variabel kepuasan wisatawan dapat dijelaskan oleh variabel fasilitas, aksesibilitas dan daya tarik wisata sebesar $62,7 \%$. Kemudian sisanya $37,3 \%$ dapat dijelaskan oleh variabel lain diluar dari variabel penelitian. Hal ini menunjukkan bahwa $\mathrm{H}_{4}$ diterima dimana Fasilitas, Aksesibilitas dan Daya Tarik Wisata secara simultan memiliki pengaruh positif dan signifikan terhadap kepuasan wisatawan berkunjung ke Bangka Botanical Garden (BBG) Pangkalpinang.

Faktor fasilitas, aksesibilitas dan daya tarik wisata serta faktor lain dapat mempengaruhi kepuasan wisatawan atas berbagai pilihan jasa yang dirasakan. Penelitian ini mendukung penelitian yang dilakukan oleh Prasojo (2017) yang berjudul Pengaruh Fasilitas, Kualitas
Pelayanan, dan Aksesibilitas Terhadap Kepuasan Pasien di Rumah Sakit Gigi dan Mulut Institut Ilmu Kesehatan Bhakti Wiyata Kediri. Hasil penelitian menunjukkan bahwa terdapat pengaruh signifikan fasilitas, kualitas pelayanan, dan aksesibilitas terhadap kepuasan pasien di RSGM IIK Bhakti Wiyata Kediri.

\section{SIMPULAN}

Berdasarkan uraian mengenai Pengaruh Fasilitas, Aksesibilitas dan Daya Tarik Wisata Terhadap Kepuasan Wisatawan Berkunjung Ke Bangka Botanical Garden (BBG) Pangkalpinang maka dapat ditarik kesimpulan bahwa hasil yang diperoleh dari semua pernyataan dari jawaban responden untuk indikator variabel fasilitas, aksesibilitas, daya tarik wisata dan kepuasan wisatawan masuk kedalam kategori tinggi.

Variabel fasilitas memiliki pengaruh yang positif serta signifikan terhadap kepuasan wisatawan berkunjung ke Bangka Botanical Garden (BBG) Pangkalpinang. Variabel aksesibilitas memiliki pengaruh yang positif serta signifikan terhadap kepuasan wisatawan berkunjung ke Bangka Botanical Garden (BBG) Pangkalpinang. Variabel daya tarik wisata memiliki pengaruh yang positif serta signifikan terhadap kepuasan wisatawan berkunjung ke Bangka Botanical Garden (BBG) Pangkalpinang. Hal ini berdasarkan analisis dimana hasil perhitungan memperoleh $\mathrm{t}$ hitung lebih besar dari $\mathrm{t}$ tabel. Variabel independen (fasilitas, aksesibilitas dan daya tarik wisata) secara simultan/bersama-sama mempunyai pengaruh yang positif dan signifikan terhadap kepuasan wisatawan. Hasil tersebut dapat diterima atau teruji dengan nilai $\mathrm{F}$ hitung lebih besar dari $\mathrm{F}$ tabel.

Peneliti menyarankan agar fasilitas yang telah tersedia dapat lebih dijaga serta dikembangkan, untuk fasilitas wc umum agar dapat ditambah di beberapa tempat seperti dekat tempat pembelian sayur dan buah maupun didekat peternakan sapi. Kemudian untuk petunjuk jalan agar bisa diperjelas lagi sehingga 
wisatawan tidak kebingungan mengingat kawasan Bangka Botanical Garden (BBG) sangat luas, seperti petunjuk arah menuju rumah adat, perternakan sapi, warung makan, mushola, wc umum, dan lainnya.

Kemudian untuk tempat sampah agar lebih diperhatikan lagi, perlu adanya perbaikan tempat sampah yang sudah tidak layak pakai serta penambahan jumlah tempat sampat pada titiktitik penting seperti warung makan, tempat pembelian sayur dan buah, tempat bersantai didekat lapangan terbuka serta titik-titik lainnya yang dianggap paling sering dikunjungi. Sedangkan untuk tempat parkir, disarankan untuk membuat beberapa tempat/pondok tertutup seperti di dekat danau, peternakan sapi, rumah adat dan warung makan/cafe. Selain itu, dapat juga menambah fasilitas rekreasi seperti fasilitas outbound ataupun kereta untuk mengelilingi kawasan Bangka Botanical Garden (BBG). Perbaikan tersebut diharapkan dapat meningkatkan kepuasan bagi wisatawan yang berkunjung ke Bangka Botanical Garden (BBG) Pangkalpinang.

Disarankan untuk dapat memperbaiki jalan secara berkala, misalnya seperti menambal jalan yang berlubang sehingga wisatawan dapat berwisata tanpa harus terkendala jalan yang kurang baik. Pengelola dapat pula melihat contoh botanical garden lainnya, seperti kebun raya Bogor yang menggunakan akses jalan yang lebih terstuktur dengan menggunakan aspal agar lebih memudahkan wisatawan berkunjung ke Bangka Botanical Garden (BBG) Pangkalpinang. Hal ini juga diharapkan dapat meningkatkan kepuasan wisatawan berkunjung ke Bangka Botanical Garden (BBG) Pangkalpinang.

Diharapkan juga dapat menambah daya tarik wisata seperti penambahan berbagai jenis binatang khas Bangka Belitung seperti Mentilin, jenis tanaman dan buah-buahan seperti tanaman Nagasari dan buah-buahan seperti enam-enam dan karamunting yang merupakan jenis tanaman khas Bangka Belitung. Selain itu agar pihak Bangka Botanical Garden (BBG) dapat membuat satu keunikan seperti ikon khusus sehingga menjadi ciri khas dari objek wisata ini.

\section{REFERENSI}

Ghozali, I. (2013). Aplikasi Analisis Multivariate dengan Program SPSS 21 Update PLS Regresi. Semarang: Badan Penerbit Universitas Diponegoro.

Marhanah, S., \& Wahadi, W. H. (2016). Pengaruh Fasilitas Wisata Dan Kualitas Pelayanan Terhadap Kepuasan Pengunjung Di Taman Margasatwa Ragunan Jakarta. Pengaruh Fasilitas Wisata Dan Kualitas Pelayanan Terhadap Kepuasan Pengunjung Di Taman Margasatwa Ragunan Jakarta, 13(1). https://doi.org/10.17509/jurel.v13i1.2134

Minrohayati., Harsasi, M., \& Pujiastuti, S. (2017). Pengaruh Kualitas Pelayanan terhadap Loyalitas Pelanggan pada Toko Buku Online Universitas Terbuka. Jurnal Manajemen Indonesia, 16(3), 155-162. https://doi.org/10.1017/CBO978110741532 4.004

Mudrikah, A., Sartika, D., Yuniarti, R., \& Satia, A. B. (2014). Kontribusi Sektor Pariwisata Terhadap Gdp Indonesia Tahun 2004 2009. Economics Development Analysis Journal, 3(2), 362-371. https://doi.org/10.15294/edaj.v3i2.3844

Prantawan P, D., \& Sunarta, I. (2015). Studi Pengembangan Desa Pinge Sebagai Daya Tarik Ekowisata Di Kecamatan Marga Kabupaten Tabanan. Jurnal Destinasi Pariwisata, 3(1), 1-8-8. https://doi.org/10.24843/JDEPAR.2015.v03 .i01.p01

Prasojo, A. (2017). Pengaruh Fasilitas, Kualitas Pelayanan, dan Aksesibilitas Terhadap Kepuasan Pasien di Rumah Sakit Gigi dan Mulut Institut Ilmu Kesehatan Bhakti Wiyata Kediri. Simki-Economic, 1(11), 2-6.

Rosyidah, E., Sunarti, A., \& Pangestuti, E. 


\section{Jurnal Ilmiah Manajemen dan Bisnis}

(2017). Pengaruh Daya Tarik Wisata Dan Fasilitas Layanan Terhadap Kepuasan Wisatawan Di Pantai Balekambang Kabupaten Malang. Jurnal Administrasi Bisnis (JAB)|Vol, 51(2), 16-21.

Replianto. (2018, Januari 10). Sejarah, profil, visi dan misi Bangka Botanical Garden (BBG) Pangkalpinang [Personal Interview].

Sugiyono (2015). Metode Penelitian Tindakan Komprehensif (Untuk Perbaikan Kinerja dan Pengembangan Ilmu Tindakan). Bandung: Alfabeta.

Sugiyono. (2017). Metode Penelitian Manajemen. Bandung: Alfabeta.

Suryadana, M. L., \& Octavia, V. (2015). Pengantar Pemasaran Pariwisata. Bandung: Penerbit Alfabeta.

Wanda, I. B. K., \& Pangestuti, E. (2018). Pengaruh Pengembangan Komponen Destinasi Wisata Terhadap Kepuasan Pengunjung. Jurnal Administrasi Bisnis (JAB), 55(3), 83-91. http://administrasibisnis.studentjournal.ub.a c.id/index.php/jab/article/view/2307

Wulandari, V., dan Wahyuati, A. (2017). Pengaruh Fasilitas, Pelayanan dan Harga Terhadap Kepuasan Wisatawan. Jurnal Ilmu Dan Riset Manajemen, 6(3), 1-20.

Wulandari, K. A. (2017). Pengaruh Physical Evidence, Aksesibilitas, Dan Pelayanan Terhadap Kepuasan Konsumen Pada Hotel Dan Resto Mitra Inn Kediri. SimkiEconomic, 01(3). 